\title{
Activism in Southeast Asian Ethnomusicology: Empowering Youths to Revitalize Traditions and Bridge Cultural Barriers
}

\section{Aktivizem v etnomuzikologiji jugovzhodne Azije: omogočiti mladim, da oživijo tradicije in presežejo kulturne pregrade}

Prejeto: 6. avgusta 2007

Sprejeto: 2. aprila 2008

Ključne besede: umetnostna vzgoja, identiteta, multikulturalnost, procesualno gledališče, oživljanje tradicije

\section{IZVLEČEK}

Začenši s kratkim pregledom strategij in aktivnosti aplikativne etnomuzikologije se pričujoči prispevek osredotoča na razvoj socialno angažiranega pristopa k omogočanju mladih Malezijcev, da se lotijo dveh vprašanj: oživljanja tradicij in preseganja kulturnih pregrad v multietnični in multikulturni družbi, v kateri so nestrpnosti često prisotne.
Received: 6th August 2007 Accepted: 2nd April 2008

Keywords: arts education, identity, multiculturalism, process theater, revitalizing

\section{ABSTRACT}

Beginning with a short overview of the strategies and activities in applied ethnomusicology in Southeast Asia, this paper focuses on the development of a socially engaged approach to empower young people in Malaysia to address two concerns: revitalizing traditions and bridging cultural barriers in a multiethnic and multireligious society where tensions often occur.

\section{Common Concerns in Southeast Asia}

The practice of ethnomusicology has been central in the professional lives of ethnomusicologists in Southeast Asia. Besides being involved in scholarly activities such as teaching, documenting, publishing, and organizing conferences, ethnomusicologists in 
Southeast Asia actively apply their knowledge to solve particular problems in the field of culture so as to bring about change in their respective societies.

In November 2004, a group of ethnomusicologists from various parts of Southeast Asia met at the Asian Music Forum organized by Prof. Ramon Santos at the National Commission for Culture and the Arts in Manila, to discuss their common concerns, issues and share ways to handle them. The conservation of traditional music and the promotion of pluralism in multiethnic societies were issues which generated energetic discussion.

For the participants, traditional music seems to be disappearing quickly due to the changing values and attitudes regarding modernity and tradition among the younger generation. In Indonesia, Vietnam, Cambodia, Malaysia, Singapore and the Philippines, modernity seems to be associated with western popular music resulting in a lack of interest in traditional music. To the young, popular music is attractive as it is current, commercially driven and disseminated using the mass media by transnational companies which are supported by large marketing budgets. On the other hand, traditional music is associated with 'backwardness' and lacks currency.

Moreover, there is little interest in traditional music because the effects of colonialism continue to shape language, education, religion, culture, tastes and the psyche of the colonized even though most Southeast Asian countries have celebrated independence for many decades. In the realm of musical culture, Eurocentric tendencies persist in the teaching, examination, composition and performance of music. As one Indonesian delegate said, "playing traditional instruments becomes something to be ashamed of, while playing western classical instruments merits higher prestige." As in Singapore, Malaysia and elsewhere in Southeast Asia, performers of traditional music are seen as of lower status and are paid less than performers in Western classical music. Music conservatories in countries like Vietnam and Singapore focus more on the training of western classical music rather than local music.

Although ethnomusicologists in the region have taken on the urgent task of documenting fast disappearing oral traditions especially in places where village masters are getting old, this is not enough. All the delegates at the conference agreed that "they need to take steps to sustain their traditional musics, including steps to ensure that the young know about their traditions and begin to perform them." A delegate from Cambodia expressed the need to »understand the world of the youth and to find ways and means to accommodate them within the framework of Asian musical traditions. "Youths are cultural beings who make informed choices. Education is one way of providing youths with knowledge that can shape these choices," he stressed.

Indeed, education plays a very important role in revitalizing and rekindling the interest of youths in traditional music. With their knowledge of the diverse musics of the region, ethnomusicologists play important roles in educational policy-making. They are at the forefront of deconstructing colonial discourses and challenging Eurocentrism in the education system. In countries such as the Philippines, Malaysia, Indonesia, Singapore and Thailand, they have been responsible for the introduction of indigenous musics in public schools which until recent decades focused on European music theory and 
history. They have helped to develop new music curricula in schools with emphasis on traditional music, write textbooks, and even conduct workshops for teachers in traditional music. They have also attempted to innovate and compose new works based on traditional music that can attract the young.

Another issue which is of concern to Southeast Asian ethnomusicologists is the maintenance of cultural diversity and the promotion of tolerance among youths in multiethnic societies. In countries where multiethnic communities live side by side such as Malaysia, Indonesia, and the Philippines, ethnomusicologists have lobbied for multiculturalism and pluralism so that minority cultures are not marginalized. For them, multiculturalism in music means recognizing the integrity of the musical expressions of all peoples. Ethnomusicologists facilitate festivals, performances and workshops and bring traditional artists to schools to promote multiculturalism. Very often, it is up to them to make sure that the music syllabus of schools and school textbooks include the cultures of multiethnic societies. Through education, children learn to be more inclusive and tolerant of other races.

This paper looks at the development of a socially engaged approach to empower young people in Malaysia to address the two concerns outlined above: (1) revitalizing traditions and (2) bridging cultural barriers in a multiethnic and multireligious society where tensions often occur. ${ }^{1}$ I shall focus on the methods and strategies used in heritage projects known as Anak-Anak Kota (Children of the City) conducted in the multicultural inner city of Penang. Young participants learn to appreciate their own and other cultures through these multiethnic community-based projects which engage them in ethnomusicological tasks such as fieldwork, interviews, participant observation, audio-visual recording, analysis, learning traditional instruments and performing the musics of various ethnic groups. The process and performances provide a platform for young people to address issues of identity, heritage as well as to learn and explore how their diverse cultural and historical identities are rooted in a common inherited environment.

In multiethnic and multireligious societies, the appreciation of cultural diversity and the opportunity to work intensively and perform with 'others' help to build bridges, enhance tolerance, create respect for the 'other' and so manage conflict. ${ }^{2}$ By creating their own musical pieces based on fieldwork, interviews and skills in playing instruments, the young participants acquire tools for cross-cultural conservation. The young participants then 'give back' to the communities (from whom they obtained their materials for composition) through performances in the communities.

The ethnomusicologist here acts as a facilitator and catalyst for change. By crossing stylistic and ethnic boundaries and appreciating cultural differences, they help children

\footnotetext{
Malaysia has a population of 18.4 million. According to the Population and Housing Census of 1991 (Department of Statistics: 1993), 60.6\% are Bumiputera (Malays and other indigenous groups such as the orang asli, Kadazan, Bajaus, Bidayuh, Melanau, Penan etc.), $28.1 \%$ Chinese (of different dialect groups), $7.9 \%$ Indians (originating from different parts of India) and $3.4 \%$ others (which includes Arabs, Eurasians, Indonesians etc.). Discourses of Bangsa Malaysia (Malaysian Race) and the rise of a new multiethnic middle class promoting universal values and religious tolerance at the turn of the century have contributed towards pluralism and provided hopes for the creation of a more inclusive notion of Malaysian nationhood. Nevertheless, ethnicism still persists in Malaysian politics and many aspects of the daily lives including culture of the people.

See Pillai (2002a and 2002b) for an analysis of the development of educational theater in Malaysia. Van Erven (1992) gives a detailed account of the development of process theater in Asia.
} 
to develop perspectives that are more inclusive and so challenge the dominant discourse of ethnicism.

\section{Anak-Anak Kota - An ARTS-ED Project}

Anak-Anak Kota (AAK) or 'Children of the City' is a heritage education program for young people (between ages 10-19) which is organised by ARTS-ED, an arts education initiative of the Penang Educational Consultative Council, School of Arts, Universiti Sains Malaysia (USM) and Penang Heritage Trust. Participants come from diverse ethnic groups and social backgrounds and are auditioned through schools and orphanages in the city. They are given the choice to join the music, dance or theater programs according to their abilities and interests.

The AAK education program creates awareness and educates young residents of Penang on the importance of conserving their multicultural living and built heritage (such as architecture, cultural traditions, trades, crafts, customs, food etc). Knowledge of the multiethnic traditions, be they the performing arts, celebrations, social practices, spiritual values and languages, helps to promote understanding, tolerance and mutual respect. Young people begin to appreciate diversity and cultural differences, thereby avoiding the perpetuation of strong ethnocentric mind-sets.

The program is located in the 'field' which is the inner city of Penang (as opposed to a school classroom), to widen the scope and relevance of information, resources and materials which children can work with. Creative arts genres such as music, dance, theater, puppetry, wood carving, video or photography are employed to engage young people in exploring their community and environment.

Close links are also developed between Universiti Sains Malaysia with schools, residents of the inner city of Georgetown, non-governmental organizations (such as Penang Heritage Trust), Chinese dialect group and clan associations (Teochew Assoc, Khoo Kongsi, Cheah Kongsi), corporate sponsors and other local institutions of learning in terms of sharing knowledge, skills and human and physical resources. The project provides an outlet for USM staff to do community work and a training ground for the students of USM to practice what they have learnt.

\section{Process Theater}

The AAK multiarts projects are oriented towards 'process theater' which aims at the personal development of the child and the making of drama, music or dance by the children themselves. Process theater is an important component of educational drama in Malaysia which evolved as a combination of ideas of Bertolt Brecht and Augusto Boal as well as the concept of holistic theater (which combine various forms of performing arts) found in Asia. ${ }^{3}$ In AAK, we have adapted Augusto Boal's approach to 'theater of

\footnotetext{
See Pillai (2002a and 2002b) for an analysis of the development of educational theater in Malaysia. Van Erven (1992) gives a detailed account of the development of process theater in Asia.
} 
the oppressed' where the main objective is to 'change the people' from 'passive beings' into 'subjects, actors, transformers' through dramatic action (Boal:1979). For Boal, the audience should be involved in the creation and performance of a play. Active participation of the audience will support awareness training and problem solving at the community level. ${ }^{4}$ Brecht's ideas and theatrical tools that can stimulate an increased sense of political awareness in the minds of the audiences continue to influence many in process theater.

As the name suggests, process theater does not focus on performance as the sole purpose of theater but the process of creating theater is equally important. In process theater, communities communicate their views, common problems and formulate plans for development through the theater process. Also known as community theater, people's theater, theater in education or community theater, process theater has been an effective tool for conscientizing communities in Latin America, Africa and Asia since the 1970s (Epskamp 2006: Chapter 1).

The pioneer of process theater in Asia is The Philippines Educational Theater Association (PETA) which serves as a reference for the development of similar types of theater in the region. Politicized by the atrocities of the Marcos regime, PETA held theater workshops among farmers, workers and other communities throughout the Philippines in the 1970s where they explored a variety of social issues through drama, dance and music. Since then, similar types of process theater have emerged in Thailand, Indonesia and Malaysia (Van Erven: 1992) which have been adapted for raising awareness regarding heritage, peace building as well as helping children and adults cope with trauma caused by natural disasters such as the tsunami.

Adapting and localising process theater, AAK projects provide the environment in which the young person can explore issues and themes important to the Penang community through play, music, dance or drama. The project provides an open and safe space or context for expression away from young people's homes or schools. The children themselves decide what to do and how to create their musical, dance or theatrical pieces. Facilitators guide them through a series of games, exercises, improvisations and skill training.

AAK also embraces the concept of holistic theater (combining music, dance, drama, puppetry, visual arts) and the educational function of theater found in Asia. Integrating the arts is not new as the traditional performing arts in Asia often fuse dance, music, drama and visual arts. AAK promotes a sense of appreciation of local traditional forms and challenges stereotypes and myths about traditions of other races.

\section{Three phases of Process Theater}

Each project is divided into three phases: warm-up, development and closure. Warmup sessions help the participants and facilitators to get to know one another and establish

Augusto Boal was influenced by Paolo Freire (1972), the Brazilian educator and philosopher who initiated participatory learning methods in adult education and literacy training. For more discussion about definitions, contexts, applications of process theater, see Epskamp 2006: chapter 1. 
a sense of ensemble and trust through games and group dynamic activities. For instance, in order to form the longest line with their bodies, participants who do not know each other at the start of the program, will need to discuss and collectively come out with a strategy. They begin to feel comfortable with each other after a few such games.

The development phase is the most intensive and can last from 3-4 months. Participants undergo skill training in selected traditional and contemporary art forms, conduct research in the community to collect materials and compose using the materials they have gathered. Participants who choose to enter the project through music undertake ethnomusicological tasks such as learning to play traditional instruments from traditional artists, improvising music with everyday objects and body parts, and using their voices in different ways. Field trips are arranged so that participants can listen, record (using MP3 players and video cameras) and collect sounds of the environment, observe movements of and interview specific people at specific locations. The participants then put together what they have observed, collected from the field and musical instruments learnt in the form of a musical composition. Through this process, the participants have a better understanding of culture and identity, appreciation of local traditional arts and develop new pieces with distinct Malaysian elements and imagery. They are encouraged to express their views in the process, become more confident, and learn to care for one another.

The program culminates in a workshop showcase or exhibition where traditional and contemporary arts are combined as a means of understanding the self, community and environment. The community is invited as the audience and to evaluate the show. During the closure, feedback is obtained from the participants regarding the process and workshop showcase.

\section{Experiencing Multiculturalism and Revitalizing Traditions through Kisah Pulau Pinang 2006}

The following section focuses on the AAK 'Music of Sound' project which I conducted from February-July 2006 for 25 young people (aged 10-18) from various ethnic and social backgrounds. They mapped and interpreted the cultural heritage and history of the different communities in the inner city of Penang through music and song. This project culminated in the performance of Kisah Pulau Pinang (The Story of Penang) on July 15, 2006 at the Khoo Kongsi. The composition traces the history of early Penang as a meeting place for diverse peoples and cultures where conflicts and contests for economic and political power also took place.

\section{(i) Heritage Walks}

How did the young participants learn about and experience multiculturalism in Penang? They were taken on heritage walks in the inner city to discover for themselves the development of Penang as a cosmopolitan and multicultural port and city endowed with a wealth of spiritual and artistic traditions. As an important port for the trading of spices and the export of tin and rubber, Penang attracted settlers from the Malay Ar- 
chipelago, Thailand, Burma, Hadhramaut, India, China, and Europe in the $18^{\text {th }}$ and $19^{\text {th }}$ centuries. The island was also an important stopover for Muslim pilgrims in the region who were going to Mecca. The young people explored the multiple places of worship situated near each other in the inner city, names of streets, eclectic food and architecture, varied languages spoken, and street performances which showed them that Penang was a place where different peoples met and interacted in the past.

\section{(ii) Learning Traditional Music}

At the same time, the youths underwent training in playing the musical instruments of the Malay shadow puppet theater and gamelan as well as local street genres such as boria singing, pantun (poetry) recitation, Chinese chanting and dondang sayang which were often performed by local musicians in the streets of Penang ${ }^{5}$. The young people were taught the instruments and songs (lagu) of the Malay wayang kulit (shadow play) ${ }^{6}$ such as Lagu Pak Dogol (song accompanying the clown Pak Dogol), Lagu Perang (song accompanying fighting scenes), Lagu Bertabuh (opening song announcing the beginning of the performance), and Lagu Hulubalang (song accompanying warriors). They learnt techniques of playing the gamelan instruments and musical pieces such as Timang Burung and Dayung Sampan. The instruments and musical pieces of the gamelan and wayang kulit were then incorporated into the story. Many of the participants who did not have any knowledge of wayang, gamelan, boria or dondang sayang music found the music exciting and enjoyed performing the traditional and newly-composed music. The process sparked off an interest in traditional music among participants.

\section{(iii) Making Music with Objects and Sounds of the Environment}

The young participants were also taught how to make music using everyday objects (such as bottles, tins or cups) which they collected from the environment and different parts of their bodies. By incorporating environmental sounds and making music based on sounds they heard in the streets of Penang, the children learnt that everyone can make music if given the opportunity, necessary tools and skills.

\section{(iv) Fieldwork in the Inner City}

The children were challenged to collect sounds and conversations from the port of Penang where the import and export of goods still take place, coffee shops and

\footnotetext{
The boria is a popular form of Malay musical theater which originated in Penang in the late nineteenth century. Brought by Indian Muslims soldiers, the early boria was performed to commemorate and to mourn the death of Saidina Hussein, the leader of Syiah Islam during the first ten days of Awal Muharram (the first month of the Muslim calendar). Troupes went from house to house and performed in the streets of Penang a series of comic sketches (regarding topical issues) interspersed with dance and song sequences. Dondang sayang [meaning 'love song'] is an elaborate form of Malay poetry singing which is accompanied by a violin, an accordion, two Malay frame drums and a gong. The peranakan Chinese who have adapted to Malay language and culture perform dondang sayang in the streets of Penang on the $15^{\text {th }}$ night of Chinese New Year. See Matusky and Tan (2004) for more information.

In wayang kulit or shadow puppet theater, stories of the Ramayana are told by a puppeteer who manipulates the puppets behind a screen. There are different types of wayang kulit in Malaysia. Wayang Kulit Kelantan is the most popular form. The ensemble consists of various types of drums namely the goblet-shaped gedumbak, barrel-shaped gendang and geduk, kesi (cymbals), canang (a pair of gongs on a rack), tetawak (a pair of hanging gongs) and serunai (4-reeded shawm) (see Matusky and Tan 2004: 18-34).
} 
markets where diverse ethnic groups communicate in a mixture of languages, different places of worship such as the Indian Mariaman Temple, Chinese Kuan Yin Temple and the Muslim Acheh Street Mosque as well as the busy Little India where lively trading of clothes, spices, food and DVD's of Tamil and Hindustani film music take place daily. Reading about the history of Penang and interviews with old spice traders, stevedores, cargo handlers and cooks in the inner city about early migration and trades were also part of fieldwork.

\section{(v) Musical Composition Showing the Multicultural History of Penang}

Interpreting heritage through music and song was the next step in the process. The musical production, 'Kisah Pulau Pinang', was a combination of fieldwork materials collected and skills learnt in playing traditional musical instruments and everyday objects. The musical composition began in a market place (accompanied by gamelan) where various ethnic groups met and interacted daily in early Penang. This was followed by a boria presentation about the formation of Penang as a multicultural and cosmopolitan port and an important stop for pilgrims going to Mecca.

Boria Pulau Pinang (chorus and selected verses)

Kisah Pulau Pinang tajuk dan tema

Tempat persinggahan berbilang agama

Pelbagai bangsa bercampur bersama

Boria anak kota dendang seirama...

Rempah diimport dari India dan Burma

Lada dari Acheh, teh dari China

Ramai pedagang datang bersinggah

Seluruh kota riuh-rendah jadinya...

\section{Dari Malaya, Siam dan Sumatera}

Singgah di Lebuh Acheh, tujuannya sama

Sambil tunggu Kapal Haji ke Mekkah

Duduk di Masjid dengar ceramah...

Translation: The story of Penang is the topic and theme [of this boria]

[It is] A place where people of various religions sojourned

Diverse races mixed together

Boria 'Children of the City' is sung in harmony ...

Spices are imported from India and Burma

Pepper from Acheh, tea from China

Many traders stopped [at the port]

The whole town became a din... 
From Malaya, Siam and Sumatera

[Many came] to Acheh Street with the same intention

While waiting for the pilgrimage boat to Mecca

[They] listened to talks at the Mosque....

How immigrants arrived in Penang was portrayed through the chants of two main characters, an Indian Muslim and a Chinese. They sang about how they came to Penang from India and China respectively. The former was a spice trader while the latter used to carry people and goods in his small boat from the big ships which landed out at sea to the shore. Their life histories were followed by a work song of stevedores based on Tamil and Malay (italics) words collected during fieldwork.

\section{Work Song of Stevedores}

Haria (x4)

Masuk Tongkang, Lima kupang

Upah Kuli oru valli (x4)

Lego (x16)
[Term used when lowering goods to the boat] Enter the boat, fifty cents

Pay the worker twenty cents

[Term used when lifting goods from the boat]

The coming together of different peoples in Penang was manifested in the names of the streets, places of worship belonging to different religions at close proximity to each other, as well as eclectic food and architecture, multiple languages spoken, and street festivals. The participants of the project were given an opportunity to perform their small pieces based on sounds they heard and movements they witnessed during fieldwork. They reenacted scenes in the Indian and Chinese temples through music and movement and used a mixture of languages heard in the streets, coffee shops and temples. The multiethnic musical traditions as well as new contemporary genres such as rap formed the basis of these new pieces composed by the children.

Rap on the Streets of Penang (italics = Malay; CAPS = Hokkien, ordinary font = English)

Penang ah Penang

Banyak jalan banyaklah nama

Itu nama mana datang?

AH KONG AH MA brother sista kamu semua cai em cai

Dulu2 nama jalan diberi kerana nama bangsa orang2 di Penang

Malay Street, Acheen Street

Bangkok Lane, Swatow Lane

Yahudi Road, Burmah Road

Ceylon Lane, Amoy Lane

Kampung Jawa, kampong Malabar.

ANG MO LANG EH MIA pun ada

King Street, Queen Street, Campbell Street, Victoria Street 
Orang Cina pula ikut nama perniagaan

THUAN LO SIN KAY SI New Textile Street

PAK THEEK KAY SI Iron Smith Street

THAI GU AU SI Cow Slaughtering Street

KIAM HU THNIA SI Salted Fish Place

PHAK CHEOK KAY SI Tombstone Makers Street

Translation: Penang ah Penang

Many roads many names

Where did the names come from?

Grandfather, grandmother, brother, sister do you all know?

In the past the roads were named following the races of the people in Penang

Malay Street, Acheen Street

Bangkok Lane, Swatow Lane

Yahudi Road, Burmah Road

Ceylon Lane, Amoy Lane

Java village, Malabar village.

There are also roads which were named after English people

King Street, Queen Street, Campbell Street, Victoria Street

Chinese people named roads following the businesses there

THUAN LO SIN KAY SI New Textile Street

PAK THEEK KAY SI Iron Smith Street

THAI GU AU SI Cow Slaughtering Street

KIAM HU THNIA SI Salted Fish Place

PHAK CHEOK KAY SI Tombstone Makers Street

The children were joined by 64-year old veteran performer Mohd Bahroodin Ahmad, the recipient of the Living Heritage Treasures of Penang Awards 2005, who sang a dondang sayang based on a pantun which he had composed about the delicious eclectic foods of Penang including curry laksa, nasi kandar, mee rebus and nyonya kuih.

Dondang Sayang (on the eclectic food of Penang)

Naik langcia pusinglah bandar

Lauknya kari ikanlah segar

Kalau lu makan nasilah kandar

Orang curi isteri lu sedar lu tak sedar

Sungguhlah indah cahaya litin sambil mencecah buahlah bacang
[I]go around town in a trishaw

The gravy in the fish curry is so refreshing If you eat nasi kandar (type of dish prepared by Indian Muslims) You will not even be aware that people have stolen your wife

The light of the candle is truly beautiful While tasting the horse mango 
Singgahlah juga di Swatow Lane

Makan popia hai kacang dan ice kacang.
[I] Stop by Swatow Lane

To eat popia and ice kacang (Chinese dishes).

With so many different peoples coming together in Penang in the late nineteenth century, it was inevitable that contests for economic and political power occurred. In particular, conflict broke out with the formation of secret societies which were actually multiethnic alliances to gain control of the tin mining industry and political power. The boria which was then performed during Awal Muharram (the first week of the Muslim calendar), was in fact used by competing secret societies such as the Malay Bendera Merah (which ganged up with the Hokkien Khian Teik) and the Malay Bendera Putih (which ganged up with the Cantonese Ghee Hin) in Penang to instigate each other to fight. In the musical composition of Kisah Pulau Pinang, the young people employed the Lagu Perang (used in fighting scenes of Malay shadow play) and combined it with interlocking bamboo rhythms to accompany the fight between the two secret societies.

\section{(vi) Back to the Community}

The final showcase or performance was held in an open space in the inner city with the community as the audience. It was a wonderful experience watching the young and old in the audience commenting on what was happening on stage, laughing, recalling their past, clapping and cheering the children on stage as they watched their stories, actions and music being performed. Through performance, the children themselves were able to internalize what they had learnt about Penang's history, multiculturalism and traditions.

\section{Evaluations}

\section{(i) A Platform for Revitalizing Traditions}

Based on focus interviews and questionnaire evaluations, AAK workshops such as Kisah Pulau Pinang have provided a platform for young participants to learn and appreciate their own and other cultures through ethnomusicological practices such as research, oral interviews, observation, audio-visual recording, analysis and composition. Learning to perform traditional instruments and repertoire of various ethnic groups has helped to reinforce respect for the children's own and other cultural traditions. Oral interviews have exposed the young participants to and stimulated the recovery of histories which are not found in history texts. Some of these histories did not have any meaning for participants before they joined the projects. Understanding the history of migration and syncretism in Malaysian cultures have helped participants to understand the self and address issues of identity.

Performances of the musical production of Kisah Pulau Pinang in the community (from whom the materials were obtained) have stimulated interest and pride in community members and the young performers to revitalize traditions which are disappearing. As a participant said, "I thought that traditional music was 'boring' before I started play- 
ing the gamelan. Now I want to learn and play more gamelan”. Fusion music is attractive as 'tradition' gains currency, the young people get to create the music themselves and local traditions are injected with new colours. The experience has been empowering for both performers and community. In a sense, the project has brought to light the four strategies in applied ethnomusicology that Sheehy (1992) advocates: "developing new performance frames"; "feeding back musical models to the communities that created them", "empowering community members to become musical activists"; and "developing broad structural solutions" ${ }^{7}$

This project is also an attempt to bring community theater back to Penang. In the past, Penang was known for street performances such as Chinese Opera, boria, dondang sayang, ronggeng, menora which were performed by different ethnic groups during festivals throughout the year. Although some performances are still held in the streets today, the tradition is slowly fading away. AAK productions have helped to revitalize community performances which attract multiethnic audiences by mixing languages, musical forms, instruments and genres. They are steps which assist in reclaiming a viable role and restoring a meaningful place for traditional music in the community. Favourable reception by audiences can raise the status of traditional music.

\section{(ii) A Platform for Cross Cultural Understanding and Interaction}

AAK projects have encouraged cross-cultural understanding and interaction by incorporating participants, artists and facilitators from different ethnicity and class backgrounds. The young participants have been given a safe space to relate intensively with others outside their own racial group. As a Chinese school participant emphasized: "I rarely mix with other races because I go to a Chinese school where all the students are Chinese...at this workshop, I have the chance to mix." The participants began to feel comfortable with one another through 'getting-to-know-you' and team building games which were introduced at the beginning of the workshop. Another young participant said, "playing games helps us to interact and to develop trust among friends of different races."

The AAK participants were involved in different forms of border crossings in the learning and production process which helped in integration. The story, music and movements employed were based on experiences of real life people of various ethnic backgrounds in the inner city of Penang. The characters mixed Hokkien, Malay, English, Tamil and Mandarin phrases embodying typical conversations at the Malaysian market place, coffee shop, homes and schools.

The participants were introduced to different types of indigenous musics and theater using traditional transmission methods and were encouraged to experiment with different Southeast Asian aesthetics. The musical ensemble combined the Malay wayang kulit (shadow play) drums and gongs, instruments of the gamelan, Malay kompang (frame drum), Chinese woodblocks as well as the Western violin. Multiculturalism was

\footnotetext{
AAK has produced pamphlets of the endangered trades and crafts based on research and interviews by the young participants of the program. Craftsmen such as those who make lanterns, sign boards, traditional costumes, local food and drinks distribute these pamphlets to visitors who visit them. Dissemination of materials collected by the young participants in the form of flyers and pamphlets to the general public has brought a renewed sense of significance to the community and encouraged them to sustain their art and crafts.
} 
also employed in the mixture of Malay, Hokkien, Mandarin, Tamil and English texts and 'call and answer' technique often found in Chinese and Malay folk singing. The combination of Malay boria, wayang kulit, gamelan and pantun, with Chinese chant and peranakan dondang sayang, also exemplified intercultural mixing. Nevertheless, the diverse sounds and styles were framed by the polyphonic textures and interlocking rhythms of Southeast Asian music.

Furthermore, intercultural mixing was encouraged during the workshop as the participants from diverse ethnic and social backgrounds had to interact intensively with one another for 4-6 months and to negotiate with one another in the improvisation and learning process. If they had problems with one another, they had to resolve them so that the performance could go on. Enjoyment in being involved in the production also helped to ease any tensions that arose during the rehearsals. The participants were quick to add that "no work can be done individually in the workshops; we have to cooperate and work as an ensemble."

Additionally, observing, recording and executing the movements or playing the music of another ethnic group helped the participants to learn more about the 'other'. For instance, the Chinese and Eurasian children who visited the Indian temple expanded their knowledge about Indian religion and culture. One Chinese participant added that she had never visited a mosque in her life [before the project] and that her Malay friend at the workshop 'explained how Muslims pray at the mosque.' The Malay girl in turn declared that she learnt about the customs of the Chinese and Indians, the way they pray, dress, interact with one another and their food' through the project. The lead character playing the role of the Indian Muslim (known locally as mamak) woman had to observe a similar character to distinguish her manner of speech and body movements. Through interviews with traders and cooks about various spices, the young participants learnt more about the eclectic food prepared by different communities in Penang.

By way of conclusion, community-based music and heritage conservation programs with the ethnomusicologist acting as facilitator, have empowered young people and the community to transcend ethnic barriers and take courage to speak for themselves.

Empowerment ensures that musical traditions will be conserved in their traditional socio-cultural contexts of performance, rather than in the archives.

Music and the arts are important entry points for children to cross ethnic barriers. Children are ever ready to play the music or to study the characters of other ethnic groups as they see the activities as part of skill building leading towards a musical performance. In the process, they learn to understand and respect other cultures and lose any preconceived notions that they might have of these cultures. This helps in integration. At the end of the workshop, the children do not see themselves as Malays, Indians, Eurasians or Chinese but as Malaysians and participants of the workshop.

Community process-oriented arts projects involve hard work, dedication and giving up one's weekends. It is not likely to win arts awards and there is no instant gratification of bouquets in the theater lobby while financial support can be difficult. The process of revitalizing traditions and promoting intercultural mixing through projects such as AAK is slow but it is a beginning. 

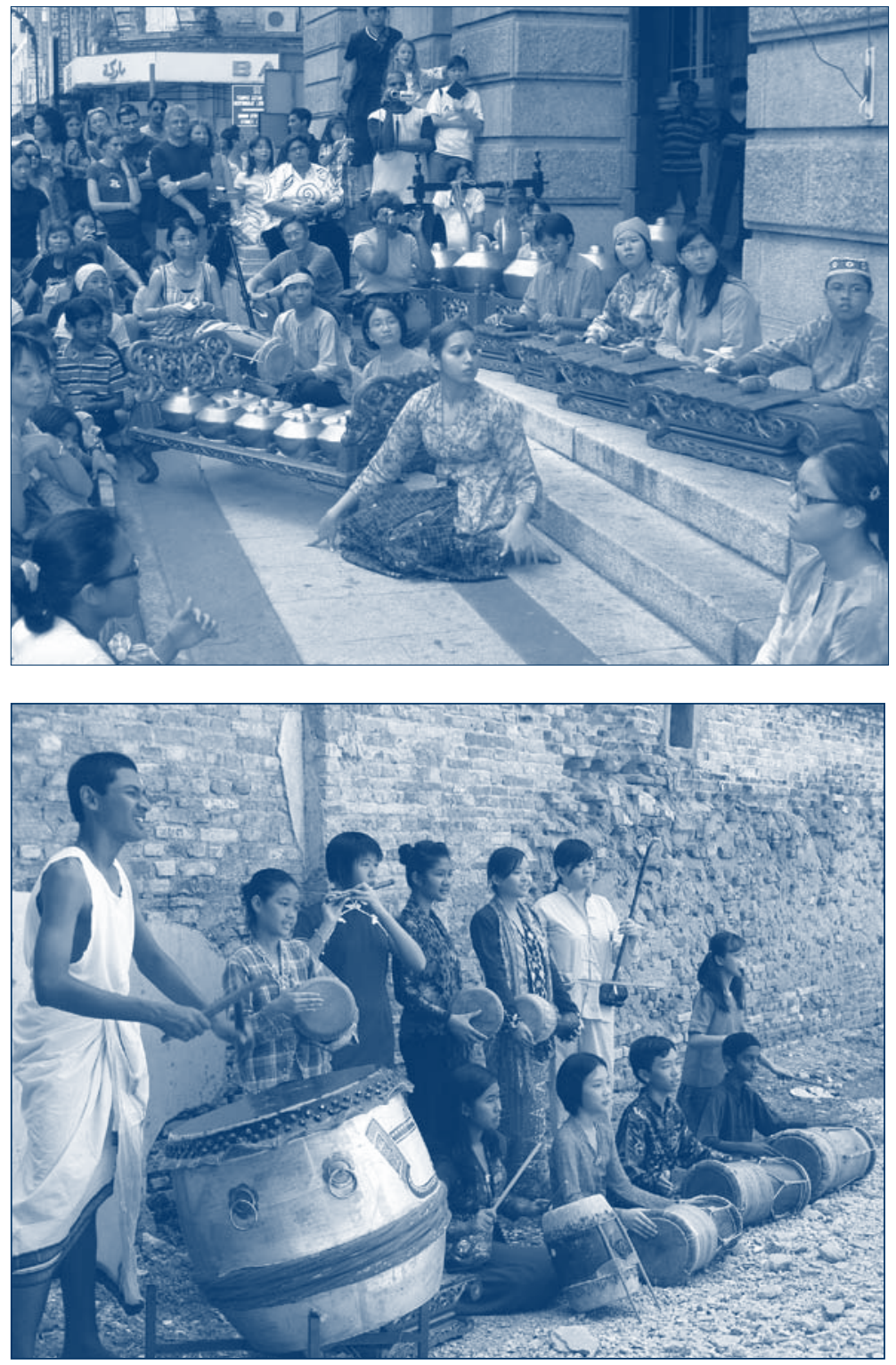

\section{Bibliography}

Boal, Augusto. 1979. Theater of the Oppressed. New York: Urizen Books.

Davis, Martha Ellen. 1992. "Careers. "Alternative Careers," and the Unity Between Theory and Practice in Ethnomusicology', Ethnomusicology 36/3: 361-388. 
Eskamp, Kees. 2006. Theater for Development, An Introduction to Context, Applications and Training. London: Zed Press.

Freire, Paolo. 1972. Cultural Action for Freedom. Harmondsworth: Penguin.

Furnivall, J.S. 1944. Netherlands India: A Study of Plural Economy. New York: Macmillan.

Impey, Angela. 2002. 'Culture, Conservation and Community Reconstruction: Explorations in Advocacy Ethnomusicology and Participatory Action Research in Northern Kwazulu Natal'. Yearbook for Traditional Music 34: 9-24.

Matusky, Patricia and Tan Sooi Beng. 2004. The Music of Malaysia, The Classical, Folk and Syncretic Traditions. SOAS Musicology Series, Aldershot: Ashgate Press.

Pillai, Janet. 2002a. 'We Need a Past to Create the Present: The Significance of Tradition in the Development of Theater for Young People in Malaysia', Wacana Seni, Journal of Arts Discourse 1: 55-70.

Pillai, Janet. 2002b. 'Deepening Engagement and Enlarging Spaces: Public Engaged Art Practice in Malaysia,' Focas, Forum on Contemporary Art and Society, 4.

Seeger, Anthony. 2006. 'Lost Lineages and Neglected Peers: Ethnomusicologists outside Academia'. Ethnomusicology 50 (2): 214-235.

Sheehy, Daniel. 1992. 'A Few Notions about Philosophy and Strategy in Applied Ethnomusicology', Ethnomusicology 36 (3): 323-336.

Tan Sooi Beng. 2003. 'Multi-Culturalism or One National Culture: Culture Centralization and the Recreation of the Traditional Performing Arts in Malaysia,' Journal of Chinese Ritual, Theater and Folklore, Shih Ho-cheng, Folk Culture Foundation, Taipei, 141, September, 237-259.

Tan Sooi Beng. 1993. Bangsawan, A Social and Stylistic History of the Malay Opera. Singapore: Oxford University Press.

Van Erven. 1992. The Playful Revolution, theater and Liberation in Asia. Bloomington and Indianapolis: Indiana University Press.

POVZETEK

Etnomuzikološka praksa je bila in je osrednje področje delovanja etnomuzikologov jugovzhodne Azije. S svojim védenjem o različnih regionalnih glasbah etnomuzikologi igrajo pomembno vlogo $\mathrm{v}$ kulturni in vzgojni politiki. Njihovim naporom je pripisati vključitev staroselskih glasb v javno šolstvo, ki je bilo doslej usmerjeno v evropsko glasbo. Prav tako so med prvimi, ki dokumentirajo tradicije obsojene na nevarnost izginotja.

Začenši s kratkim pregledom strategij in aktivnosti aplikativne etnomuzikologije se pričujoči prispevek osredotoča na razvoj socialno angažiranega pristopa k omogočanju mladih Malezijcev, da se lotijo dveh vprašanj: oživljanja tradicij in preseganja kulturnih pregrad $\mathrm{v}$ multietnični in multikulturni družbi, v kateri so nestrpnosti često prisotne. Mladi se v okviru multietničnih projektov, ki slonijo na raziskovanju posameznih skupnosti, naučijo ceniti lastno kakor tudi druge kulture, in sicer na podlagi etnomuzikoloških nalog, kot so terensko delo, intervjuji, opazovanje, avdiovizualno snemanje, analiza, poznavanje tradicijskih glasbil ter izvajanje glasb različnih etničnih skupin. V multietničnih in večverskih družbah vrednotenje kulturnih različnosti in možnost intenzivnega dela ter muziciranje z "drugimi" pomaga pri gradnji mostov, razvijanju strpnosti in upoštevanju "drugačnega", kar omogoča obvladovanje sporov. S tem da ustvarjajo lastne glasbene stvaritve, ki slonijo na terenskem delu, intervjujih in instrumentalnih veščinah, si mladi udeleženci pridobivajo orodja oziroma sredstva za vsestransko ohranjanje različnih kultur. 